\title{
Pengaruh profitabilitas, leverage, likuiditas, struktur modal dan keputusan investasi terhadap nilai perusahaan pada perusahaan sektor keuangan yang terdaftar di Bursa Efek Indonesia Tahun 2015-2017
}

\author{
Peffi Manalu*; Getsmani; Citra Permatasari Hutagaol; Deasy Arisandy Aruan \\ Prodi Akuntansi, Fakultas Ekonomi, Universitas Prima Indonesia \\ *E-mail korespodensi: peffimanalu82@gmail.com
}

\begin{abstract}
This study aims to determine the effect of profitability, leverage, liquidity, capital structure, and investment decisions on firm value. A research approach is a quantitative approach. The study population was taken from financial sector companies that have been listed on the Indonesia Stock Exchange 2015-2017, namely from a total of 87 companies, 39 companies were taken. The sample applies the purposive sampling technique. The research successfully proves that profitability, leverage, liquidity, capital structure, and investment decisions have a positive and significant effect on firm value. Partially, the research results are only profitability which has a positive and significant effect on firm value. So that the Adj obtained. $R$ Square $13.1 \%$ with the remaining $86.9 \%$ influenced by outside variables.
\end{abstract}

Keywords: Profitability,Leverage, Liquidity, Capital structure, Investment decisions, Firm value

\begin{abstract}
Abstrak
Penelitian ini memiliki tujuan mengetahui pengaruh profitabilitas, leverage, likuiditas, struktur modal dan keputusan investasi pada nilai perusahaan. Pendekatan penelitian ialah pendekatan kuantitatif. Populasi penelitian diambil dari perusahaan sektor keuangan yang telah masuk daftar di Bursa Efek Indonesia Tahun 2015-2017, yakni dari total 87 perusahaan, diambil 39 perusahaan. Sampel memberlakukan teknik purposive sampling. penelitian berhasil membuktikan secara bahwasanya profitabilitas, leverage, likuiditas, struktur modal dan keputusan investasi terdapat pengaruh positif dan signifikansi pada nilai perusahaan. Secara parsial, hasil penelitian yaitu hanya profitabilitas yang terdapat pengaruh positif dan signifikansi pada nilai perusahaan. Sehingga di peroleh Adj. $R$ Square $13,1 \%$ dengan sisa $86,9 \%$ dipengaruhi oleh variabel luar.
\end{abstract}

Kata kunci: Profitabilitas, Leverage, Likuiditas, Struktur modal, Keputusan investasi, Nilai perusahan.

\section{PENDAHULUAN}

Di era perkembangan perekonomian saat ini sudah banyak industri jasa salah satunya sektor keuangan yang berperan penting untuk pertumbuhan ekonomi walaupun hubungannya bisa bersifat kebalikannya, dimana pertumbuhan ekonomi yang baik dapat mendorong berkembangnya sektor keuangan. Semakin berkembangnya suatu pertumbuhan ekonomi dalam negara membuat perusahaan juga berusaha untuk memberikan yang terbaik untuk memperoleh laba yang besar dan memakmurkan para pemegang sahamnya. Kinerja yang kurang bagus akan memberikan efek yang buruk bagi perusahaan yang dikaitkan dengan keuntungan yang sedikit ataupun merugikan perusahaan. 
Nilai perusahaan yang tinggi menjadi titik kepercayaan masyarakat untuk perusahaan. Nilai perusahaan dipengaruhi oleh harga saham, dengan peningkatan harga saham itulah akan membuat masyarakat percaya kepada perusahaan karena minta investor akan tinggi untuk menanakan modalnya.

Profitabilitas merupakan salah satu yang mencerminkan keadaan sehat atau tidaknya keuangan perusahaan selama beroperasinya perusahaan dan menggambarkan kemampuan suatu perusahaan mendapatkan laba yang itu untuk mempengaruhi nilai perusahaan maka ROA yang tinggi baik bagi perusahaan.

Penyebab investor mempertimbangkan investasinya yaitu dengan melihat besarmya hutang yang dimiliki perusahaan. Leverage memperlihatkan proporsi besarnya hutang dengan seluruh kekayaan yang dimiliki perusahaan. Semakin tinggi angka hutang perusahaan akan memberikan resiko terhadap keuangan perusahaan yang akan mempengaruhi investor serta menurunkan nilai perusahaan.

Likuiditas yang dimiliki perusahaan menunjukkan kepada para calon investor seberapa banyak total hutang yang dimiliki untuk membiayai perusahaan dan seberapa banyak kemampuan perusahaan tersebut menutupi hutangnya yang segera jatuh tempo. Semakin tinggi likuid maka tingkat kepercayaan investor makin meningkat sehingga berpengaruh kepada nilai perusahaan. Aktiva lancar dimanfaatkan oleh current ratio sebagai alat ukur likuiditas untuk memenuhi pelunasan hutang. Kenaikan current ratio mendorong harga saham perusahaan mencapai hasil yang tinggi.

Struktur modal yang juga membahas mengenai hutang terutama pada sumber pendanaan yang diterima perusahaan, baik dari luar perusahaan maupun dari dalam atau dapat di katakan modal asing berupa pinjaman jangka panjang dan pendek. Perbandingan nilai utang dengan ekuitas merupakan rasio dari DER yang mengatakan jika perusahaan memperoleh keuntungan lebih banyak dari pada biaya bunga maupun kewajiban pokoknya itu dikarenakan perusahaan mengelola utang dengan baik untuk perluasan usahanya.hal ini dapat diikut dengan meningkatnya harga saham.

Hal yang membuat investor tertarik adalah pada saat memutuskan investasinya ke perusahaan. Jika laba yang didapat per lembar dari saham yang beredar berjalan lancar maka akan terlihat kemakmuran pemegang saham dapat dijamin dengan melihat pembayaran dividennya. Semakin baik perusahaan menunjukkan pembayaran dividennya maka akan meningkatkan nilai perusahaan dengan mendatangkan investor lebih banyak lagi. EPS menjadi Salah satu pusat perhatian investor dikarenakan tingginya EPS suatu perusahaan maka makin besar peluang investor mendapatkan keuntungan sehingga berdampak positif bagi harga saham.

Fenomena yang terjadi pada perusahaan PT. Buana Finance Tbk, dengan jumlah total aktiva Rp. 3.629.038.000.000 di tahun 2016 dan Rp. 4.367.934.000.000 di tahun 2017 terjadi peningkatan 20,36\% dengan harga saham tahun 2016 Rp. 835 dan tahun 2017 Rp. 525 terjadi penurunan yakni 37,12\%. Fungsi aktiva ini digunakan oleh ROA atau profitabilitas sebagai alat mengukur kemampuan perusahaan meraih keuntungan. Hal itu disebabkan oleh ROA yang menaik yang berdampak pada nilai perusahaan yang juga akan menaik (syamsuddin. 2011:63). Fenomena tersebut bertolak belakang belakang bahwa naiknya total aktiva justru membuat saham menurun yang seharusnya naik.

Pada Perusahaan PT. Adira Dinamika Multi Finance, dengan jumlah total hutang pada tahun 2016 Rp. 22.665.905.000.000 dan tahun 2017 Rp. 23.747.518.000.000 mengalami peningkatan sebesar 4,77\% dengan harga saham tahun $2016 \mathrm{Rp}$. 6.750, tahun 2017 Rp. 7.125 naiksebesar 5,55\%. Kreditur lebih menyukai hutang lebih sedikit karena tampak dari jumlah aktiva pemilik modal sehingga secara tak langsung mempengaruhi peningkatam harga saham diikuti dengan resiko kecil bagi kreditur (Ircham dkk, 2014). Namum terlihat hutangnya naik justru membuat harga sahamnya naik yang seharusnya turun. 
Pada PT.Trust Finance Indonesia Tbk, aktiva lancar tahun $2016 \mathrm{Rp}$. 257.759.791.949, tahun 2017 Rp. 273.149.626.026 meningkat sebesar 5,57\% dengan harga saham tahun 2016 Rp. 192, tahun 2017 Rp. 130 menurun sebesar 32,29\%. Namun terlihat bahwa aktiva lancarnya naik justru membuat harga sahamnya turun yang seharusnya harga saham dapat ikut meningkat. Aktiva lancar dimanfaatkan oleh CR sebagai alat ukur potensi likuiditas yakni dengan cara melunasi hutang-hutang (Hani, 2015:122). Kenaikan CR mendorong harga saham perusahaan mencapai hasil yang tinggi (Rahman dan Sutrisno, 2013).

PT. Verena Multi Finance Tbk, ekuitas tahun 2016 Rp 286.741.374.000, tahun 2017 Rp. 464.248.133.000 meningkat sebesar 61,9\%. dengan harga saham tahun 2016 Rp. 149, tahun 2017 Rp. 93 menurun sebesar 37,58\%. Fenomena tersebut terlihat bahwa tingkat ekuitas naik malah membuat harga sahamnya merosot yang harusnya naik juga. Perbandingan nilai utang dengan ekuitas merupakan rasio dari DER yang mengatakan jika perusahaan memperoleh keuntungan lebih banyak dari pada biaya bunga maupun kewajiban pokoknya itu dikarenakan perusahaan mengelola utang dengan baik untuk perluasan usahanya.hal ini dapat diikut dengan meningkatnya harga saham (Kasmir, 2012:157).

Pada PT. Batavia Prosperindo Finance Tbk, EAT tahun 2016 Rp. 33.913.107.287, tahun 2017 Rp. 48.979.434.104 meningkat sebesar 44,42\%, dengan harga saham tahun 2016 Rp. 500 dan 2017 Rp. 384 terjadi penurunan yaitu 23,3\%. Fenomena tersebut terlihat bahwa EAT atau laba bersih setelah pajak menunjukkan peningkatan akan tetapi harga saham terlihat turun yang seharusnya dapat memicu kenaikan. EPS menjadi Salah satu pusat perhatian investor dikarenakan tingginya EPS suatu perusahaan maka makin besar peluang investor mendapatkan keuntungan sehingga memberikan dampak yang positif pada saham menurut harga pasaran (Mursidah, 2011).

Dari keterangan diatas ditemukan bahwa ada beragam cara untuk menilai sebuah perusahaan. Dengan hal itu kami tertarik meneliti kembali dengan menambahkan Struktur Modal dan Keputusan Investasi serta menggunakan Sektor berbeda dari penelitian lainnya seperti Nugroho (2013), Sukarya dan Bagaskara (2019) serta Andriani dan Rudianto (2019). Itulah yang mendasari kami melaksanakan riset dengan judul, "Pengaruh profitabilitas, leverage, likuiditas, struktur modal dan keputusan investasi terhadap nilai perusahaan pada perusahaan sektor keuangan yang terdaftar di Bursa Efek Indonesia Tahun 2015-2017”.

\section{TINJAUAN PUSTAKA}

\section{Pengaruh profitabilitas terhadap nilai perusahaan}

Profitabilitas menunjukkan keberhasilan perusahaan meraih profit yang bersumber dari kegiatan penjualan, jumlah cabang, modal, kas, jumlah karyawan, dan lainnya (Harahap, 2015:304). Makin besar rasio laba per saham, semakin besar potensi perusahaan memperoleh keuntungan, ini menandakan peluang semakin baik (Noor, 2014:203). Penelitian Rachmawati \& Pinem (2015) menemukan profitabilitas mempunyai pengaruh signifikansi pada nilai perusahaan.

\section{Pengaruh leverage pada nilai perusahaan}

Bagi kreditor, perlindungan akan makin besar jika terjadi likuidasi saat rasio utang rendah. Disamping itu, pemegang saham mengharapkan banyaknya leverage untuk memperbesar profit yang diinginkan (Brigham dan Houston, 2012:143). Risiko keuangan perusahaan yang tinggi akan terlihat jika semakin besarnya debt aset rasio yang ditunjukkan karena besarnya porsi dalam menggunakan hutang dalam pembiayaan investasi pada aktiva (Sudana, 2012). Penelitian Suwardika dam Mustanda (2017) menemukan leverage berpengaruh signifikansi pada nilai perusahaan. 


\section{Pengaruh likuiditas pada nilai perusahaan}

Perkembangan atas perusahaan membutuhkan modal cukup besar untuk membiayai investasinya, sebab itu investasi perusahaan dan kebijakan pemenuhan kebutuhan dana sangat dipengaruhi oleh likuditas perusahaan tersebut (Sartono, 2010). Jika current rasio rendah, memperlihatkan perusahaan kurang modal untuk membayar utang. Tapi, apabila kondisi perusahaan sedang baik, belum tentu dikarenakan oleh hasil pengukuran rasio tinggi. Hal ini bisa terjadi akibat aktiva tidak digunakan dengan baik (Kasmir, 2013). Penelitian Luthfiana (2018) dan Oktaviarni mengatakan likuiditas berpengaruh signifikansi pada nilai perusahaan.

\section{Pengaruh struktur modal pada nilai perusahaan}

Memperkuat kestabilan keuangan sebuah perusahaan sangat dikira penting, sebab perubahan pada struktur modal ditaksir dapat mengakibatkan perubahan nilai perusahaan. Turunnya nilai saham dapat dipengaruhi oleh turunnya nilai perusahaan (Fahmi, 2015:190). Tidak adanya struktur modal yang terbaik, dapat dikatakan bahwasanya struktur modal yang berubah tidak memiliki pengaruh perubahan nilai perusahaan. Tetapi jika ternyata lebih baik, maka nilai perusahaan akan mengalami perubahan yang berpotensi menghasilkan struktur modal yang baik pula (Husnan, 2012). Penelitian Hamidy, Wiksuana \& Artini (2015) mengatakan struktur modal terdapat pengaruh signifikansi pada nilai perusahaan.

\section{Pengaruh keputusan investasi pada nilai perusahaan}

Investasi jangka panjang ialah pemaksimalan nilai perusahaan, dengan kata lain memberikan kesejahteraan pemilik saham. Nilai perusahaan akan terjadi peningkatan jika suatu perusahaan mampu beriinvestasi yang berpotensi memberinya nilai yang besarny amelebihi investasi itu sendiri (Sart bbono, 2010:189-190). Besar dan jenisnya investasi akan memengaruhi tingkat keuntungannya (Mulyawan, 2015). Indikator yang dipakai yaitu Earning Per Share (EPS) hal itu diindikasikan dengan tigginya EPS akan berpengaruh terhadap besar dan kecilnya harga saham (Widoatmodjo dalam Priatina, 2012:54). Penelitian Syarif dan Alamsyah (2016) menyatakan Keputusan Investasi memiliki pengaruh signifikansi pada Nilai Perusahaan.

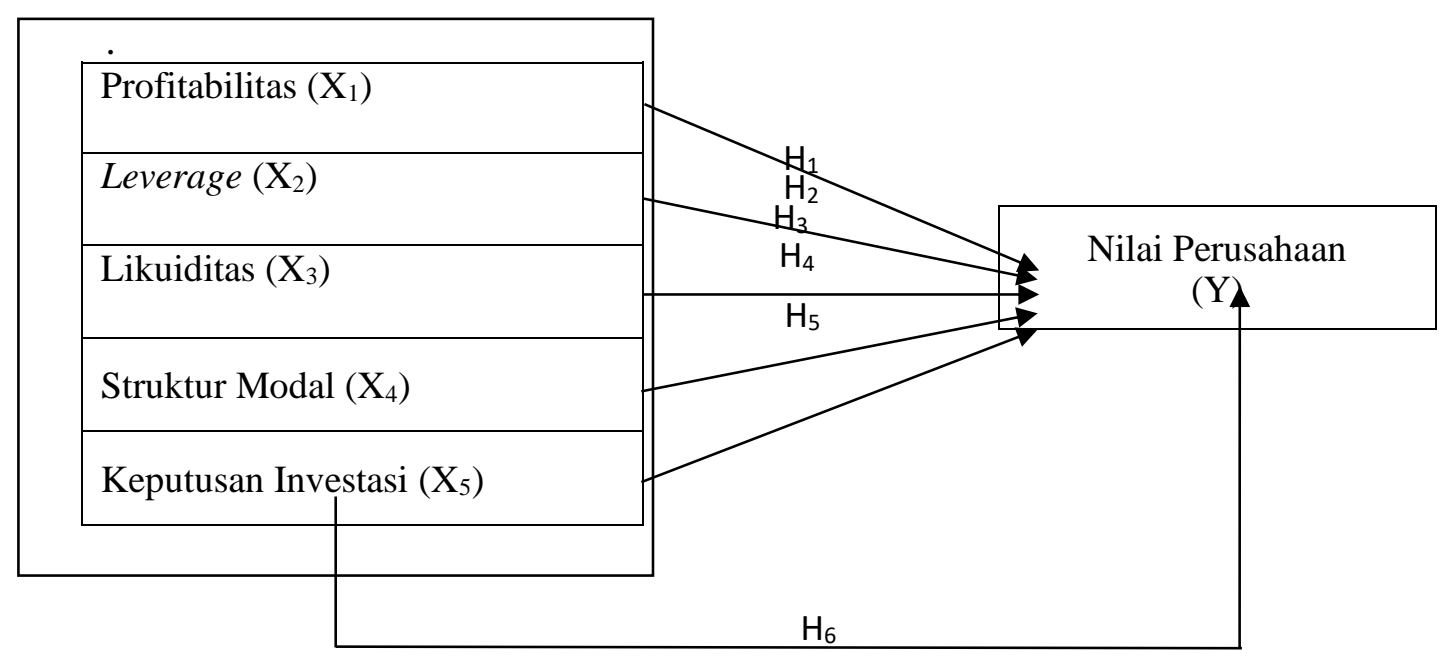

Gambar 1. Kerangka konseptual

\section{Hipotesis penelitian}

Hipotesis yaitu dugaan sementara yang harus dibuktikan kebenarannya. Berikut di bawah adalah hipotesis penelitian:

H1 : Profitabilitas memiliki pengaruh secara parsial atas Nilai Perusahaan. 
H2 : Leverage memiliki pengaruh secara parsial atas Nilai Perusahaan.

H3 : Likuiditas berpengaruh secara parsial atas Nilai Perusahaan.

H4 : Struktur Modal terdapat pengaruh secara parsial atas Nilai Perusahaan.

H5 : Keputusan Investasi terdapat pengaruh secara parsial atas Nilai Perusahaan.

H6 : Profitabilitas, Leverage, Likuiditas, Struktur Modal dan Keputusan Investasi terdapat pengaruh secara simultan pada Nilai Perusahaan

\section{METODE}

\section{Pendekatan penelitian}

Metode kuantitatif ialah metode yang berguna untuk penelitian dimana metode ini bersandar pada angka dan analisis ataupun bentuk konkrit yang diperoleh sewaktu penelitian dilaksanakan (sugiyono, 2017:13).

\section{Jenis penelitian}

Jenis penelitiannya ialah deskriptif dimana untuk memahami karakteristik dari beberapa variable dalam situasi tertentu (Hermawan dan Yusran, 2017:5).

\section{Populasi dan sampel}

Populasi penelitian bersumber dari website www.idx.co.id yang berfokus pada tahun 2015-2017 terkait dengan perusahaan sektor keuangan yang telah ada pada daftar Bursa Efek Indonesia.Sedangkan perolehan sample yakni purposive sampling. Berikut kriteria sampel :

Tabel 1. Kriteria sampel

\begin{tabular}{llc}
\hline No & Kriteria & Jumlah sampel \\
\hline 1 & $\begin{array}{l}\text { Perusahaan sektor keuangan yang terdata di BEI 2015-2017 } \\
\text { Perusahaan sektor keuangan yang tidak }\end{array}$ & 87 \\
2 & mempublis financial statement secara lengkap sepanjang tahun & $(8)$ \\
& $\begin{array}{l}2015-2017 \\
\text { Perusahaan sektor keuangan yang tidak mengalami }\end{array}$ & $(40)$ \\
$\quad \quad$ Keuntungan sepanjang tahun 2015-2017 & 3 tahun \\
Waktu pengamatan & 117 \\
Jumlah pengamatan (observasi) & \\
\hline
\end{tabular}

\section{Teknik pengumpulan data}

Data penelitian yaitu pengunaannya kajian pustaka yang mengkaji pembahasan yang berhubungan dengan penelitian yang dipelajari dari penelitian sebelumnya dan teknik studi dokumentasi dengan teknik pengumpulan laporan keuangan dan data lainnya yang dikeluarkan BEI yang bersumber website BEI (www.idx.co.id).

\section{Definisi operasional variabel penelitian}

\section{Profitabilitas} 2012:22):

Untuk indikator profitabilitas dihitung menggunakan ROA yaitu (Sudana,

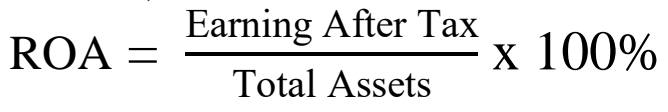

\section{Leverage}

Leverage dihitung menggunakan DAR dengan rumus (Fahmi, 2015:72) adalah: 
$\mathrm{DAR}=\frac{\text { Total Liabilities }}{\text { Total Assets }}$

Likuiditas

Indikator yang kami gunakan untuk menghitung Likuiditas yaitu CR. Rumus CR adalah (Kasmir, 2012:158):

$\mathrm{CR}=\frac{\text { Current Asset }}{\text { Current Liabilities }}$

\section{Struktur modal}

Struktur Modal dihitung menggunakan DER dengan rumus (Kasmir, 2012:158)

$\operatorname{DER}=\frac{\text { Total Utang }(\text { Debt })}{\text { Ekuitas }(\text { Equity })}$

\section{Keputusan investasi}

Keputusan Investasi menggunakan EPS sebagai berikut (Darmadji \& Fakhrudin, 2012:154):

EPS $=\frac{\text { Laba Bersih }}{\text { Jumlah Saham yang Beredar }}$

\section{Nilai perusahaan}

Nilai Perusahaan dihitung menggunakan PBV rumus (Sugiono dan Untung, 2016: 70):

$\mathrm{PBV}=\frac{\text { Harga Saham }}{\text { Nilai Buku Ekuitas }}$

\section{Uji asumsi klasik}

\section{Uji normalitas}

Berfungsi melihat adanya hubungan antar variable yang digunakan dalam penelitian menunjukkan ditribusi normal antar variable dependen maupun independen. Pada pengujian ini, analisis grafik dan pengujian statistik juga diberlakukan guna melihat adanya residu distribusi normal atau tidak normal.

\section{Uji multikolinieritas}

Berfungsi untuk memeriksa apakah ditemukannya korelasi antara variable penelitian pada model uji regresi (Ghozali, 2011:105).

\section{Uji autokorelasi}

Berguna mengidentifikasi adanya korelasi yang terdapat pada regresi linear dengan memakai uji Durbin Watson (Ghozali, 2013:110).

\section{Uji heteroskedastisitas}

Digunakan sebagai evaluasi dalam membedakan variasi residual dalam satu pengamatan ke pengamatan lainnya yang penggunaannya dengan grafik scatterplot (Ghozali,2011). 


\section{Model penelitian}

Hipotesis dilakukan dengan rumus multiple linear regression analysis ialah :

\begin{tabular}{ll} 
& \multicolumn{1}{c}{$\mathbf{Y}=\boldsymbol{\alpha}+\mathbf{b}_{1} \mathbf{X}_{1}+1$} \\
Keterangan: & \\
$\mathrm{Y}$ & $=$ Nilai perusahaan \\
$\mathrm{X}_{1}$ & $=$ Profitabilitas \\
$\mathrm{X}_{2}$ & $=$ Leverage \\
$\mathrm{X}_{3}$ & $=$ Likuiditas \\
$\mathrm{X}_{4}$ & $=$ Struktur modal \\
$\mathrm{X}_{5}$ & $=$ Keputusan investasi \\
$\mathrm{b}_{1}, \mathrm{~b}_{2}, \ldots . \mathrm{b}_{5}$ & $=$ Koefisien regresi \\
$\alpha$ & $=$ Konstanta \\
$\varepsilon$ & $=$ Standart error $(5 \%)$
\end{tabular}

\section{Koefisien determinasi}

Nilai $\mathrm{R}^{2}$ menggambarkan kemampuan variabel terikat menjelaskan variabel bebas. .Jika $\mathrm{R}^{2}=0$ berarti variable $\mathrm{Y}$ tidak bisa dijelaskan oleh variable $\mathrm{X}$, sedangkan jika $\mathrm{R}^{2}=1$ maka variable $\mathrm{Y}$ secara menyeluruh dapat dijelaskan oleh variable $\mathrm{X}$ (Priyanto, 2013:18).

\section{Pengujian hipotesis secara simultan (Uji F)}

Uji dilakukan secara bersama memiliki tujuan guna mengetahui pengaruh antara variabel dependen dan variabel independen (Ghozali, 2013:98). Dengan kriteria yaitu: 1).Bila $F_{\text {hitung }}<F_{\text {tabel }}$ maka Ho diterima dan Ha ditolak, pada $\alpha=0,05,2$ ).Bila $F_{\text {hitung }}>$ $\mathrm{F}_{\text {tabel }}$ maka Ho ditolak dan Ha diterima, pada $\alpha=0,05$

\section{Pengujian hipotesis secara parsial (Uji-t)}

Pengujian t digunakan menguji variabel terikat dengan variabel bebas secara parsial dapat saling memberikan pengaruh satu antar lain (Ghozali,2013:98). Dengan criteria yaitu: 1).Bila $t_{\text {hitung }}<t_{\text {tabel }}$, Ho diterima dan Ha ditolak, pada $\left.\alpha=0,05,2\right)$. Bila $t_{\text {hitung }}>t_{\text {tabel }}$, Ho ditolak dan Ha diterima, pada $\alpha=0,05$

\section{HASIL DAN PEMBAHASAN}

\section{Statistik deskriptif}

Statistik deskriptif berguna memperlihatkan perolehan data dari mean dan standar deviasi. Berdasatkan Tabel 1 menjelaskan variabel return on assets menghasilkan nilai minimum yakni 0,13 oleh PT. Bank Bukopin Tbk tahun 2017. Sedangkan perolehan nilai maksimal adalah 14,49 oleh PT. Danasupra Erapacific Tbk. Nilai Mean perusahaan sektor keuangan tahun 2015-2017 adalah 2,4910 dengan standar deviasi 2,49048.

Selanjutnya, berdasarkan variabel debt to total assets menunjukkan nilai minimal yaitu 0,01 oleh PT Danasupra Erapacific Tbk tahun 2017. Sedangkan, Nilai maksimalnya yakni 0,94 oleh PT Bank Bukopin Tbk. Nilai mean perusahaan sektor keuangan tahun 2015-2017 adalah 0,7169 dengan standar deviasi 0,21919.

Variabel current ratio menunjukkan nilai minimum yakni 0,08 pada PT. Bank Ina Perdana Tbk tahun 2017. Nilai maksimum yaknir 45,13 pada PT. Trust Finance Indonesia Tbk. Nilai mean perusahaan sektor keuangan tahun 2015-2017 adalah 3,2262 dengan standar deviasi 6,16383.

Debt to equity ratio nilai minimal yaitu 0,01 yakni PT. Danasupra Erapacific Tbk tahun 2015. Sedangkan nilai maksimal yaitu 14,75 oleh PT. Bank Bukopin Tbk . Nilai mean perusahaan sektor keuangan tahun 2015-2017 adalah 4,3392 dengan standar deviasi 3,13399 . 
Tabel 2. Statistik deskriptif

\begin{tabular}{crrrrr}
\hline & N & Minimum & Maximum & Mean & Std. Deviation \\
\hline ROA & 117 & .13 & 14.49 & 2.4910 & 2.49048 \\
DAR & 117 & .01 & .94 & .7169 & .21919 \\
CR & 117 & .08 & 45.13 & 3.2262 & 6.16383 \\
DER & 117 & .01 & 14.75 & 4.3392 & 3.13399 \\
EPS & 117 & .49 & 1409.15 & 117.6116 & 235.49859 \\
PBV & 117 & .26 & 17.52 & 1.6757 & 2.28509 \\
Valid N (listwise) & 117 & & & & \\
\hline
\end{tabular}

Sumber : Data diolah, 2020

Variabel earning per share menunjukkan nilai minimal yaitu 0,49 pada PT Bank Genesha Tbk. Dan Nilai maksimun yaitu 1409,15 pada PT. Adira Dinamika Multi Finance Tbk. Nilai mean perusahaan sektor keuangan tahun 2015-2017 adalah sebesar 117,6116 dengan standar deviasi 235,49859.

Variabel price to book value menunjukkan nilai minimal yaitu 0,26 pada PT. Clipan Finance Indonesia Tbk tahun 2016, dan Nilai maksimun yakni 17,52 pada PT. Asuransi Mitra Maparya Tbk. Nilai mean perusahaan sektor keuangan tahun 2015-2017 sebesar 1,6757 dengan standar deviasi 2,28509.

\section{Hasil uji asumsi klasik}

\section{Uji normalitas}

Dengan melakukan uji normalitas dapat memperlihatkan perbandingan data observasi yang berdistribusi normal melalui grafik histogram. Berikut hasil pada gambar berikut:

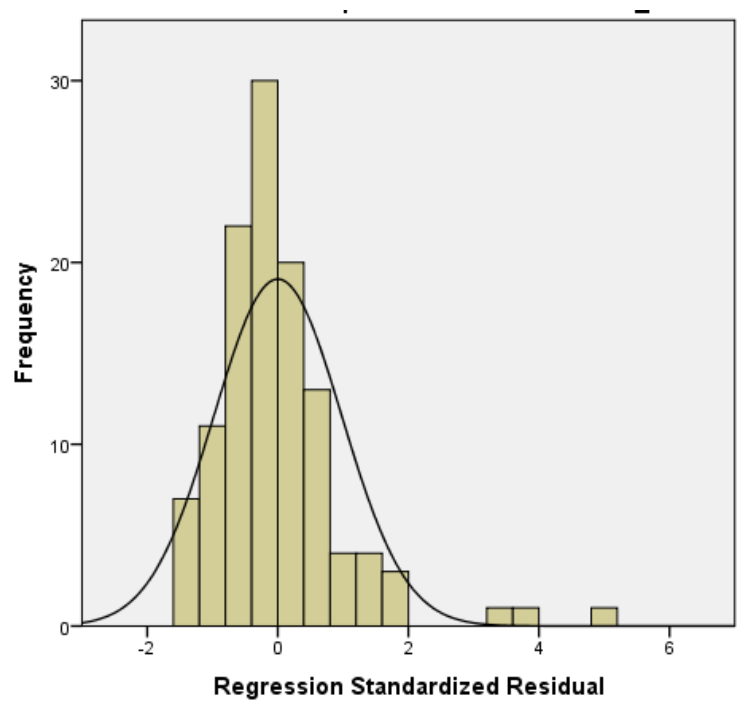

Sumber : Data diolah, 2020

Gambar 2. Histogram

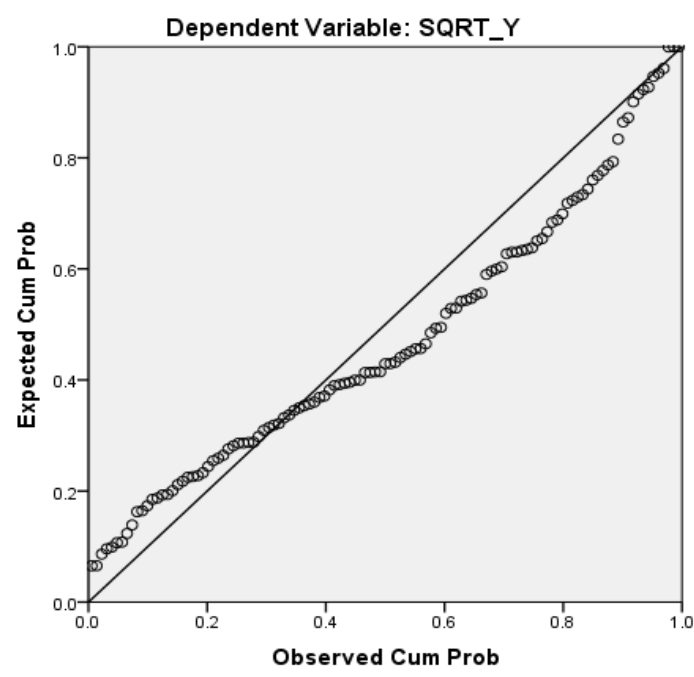

Sumber : Data diolah, 2020

Gambar 3. Probability plot setelah transformasi SQRT

Berdasarkan Gambar 2 memperlihatkan adanya garis kurva berupa simetri (U). Hal ini menunjukkan data yang digunakan dalam penelitian ini berdistribusi normal. Berdasarkan Gambar 3, menunjukan adanya kumpulan dari titik-titik yang mendekati garis diagonalnya. Hal ini menunjukkan bahwa memenuhi asumsi normalitas. Selain itu, untuk menguji normalitas juga dapat dilakukan dengan menggunakan uji Kolmogorov- 
Smirnov seperti pada Tabel 3. Berdasarkan Tabel 3, disimpulkan data terdistribusi normal pada nilai sig $0,111>0,05$.

Tabel 3. Uji normalitas Kolmogorov-Smirnov test setelah transformasi sqrt

Unstandardized Residual

\begin{tabular}{llr}
$\mathbf{N}$ & & 117 \\
\hline Normal Parameters & Mean & .0000000 \\
& Std. Deviation & .51781630 \\
Most Extreme & Absolute & .111 \\
Differences & Positive & .111 \\
& Negative & -.080 \\
Kolmogorov-Smirnov Z & & 1.203 \\
Asymp. Sig. (2-tailed) & & .111 \\
\hline
\end{tabular}

Sumber : Data diolah, 2019

\section{Uji multikolinearitas}

Berdasarkan Tabel 4, memperlihatkan segala variabel independen bernilai tolerance $>0,10$ serta nilai VIF $<10$, ialah tidak didapatkan kolerasi pada variabel bebas, atau dapat dikatakan bebas multikolinieritas.

Tabel 4. Uji multikolinearitas setelah transformasi sqrt

\begin{tabular}{llcc}
\hline & & \multicolumn{2}{c}{ Collinearity Statistics } \\
\cline { 3 - 4 } Model & & \multicolumn{2}{c}{ Tolerance } \\
\hline 1 & (Constant) & .364 & 2.744 \\
& SQRT_ROA & .294 & 3.399 \\
& SQRT_DAR & & \\
& SQRT_CR & .583 & 1.715 \\
& SQRT_DER & .271 & 3.690 \\
& SQRT_EPS & .679 & 1.472 \\
\hline
\end{tabular}

Sumber : Data diolah, 2019

\section{Uji autokorelasi}

Berdasarkan Tabel 4 memperlihatkan nilai DW 2,058. Nilai $\mathrm{dl}=1,6105$, nilai du $=1,7883$ maka du $<\mathrm{dw}<4-\mathrm{du}=1,7883<2,058<2,2117(4-1,7883)$ maka dikatakan tidak terdapat autokolerasi.

Tabel 5. Uji autokolerasi setelah transformasi sqrt

\begin{tabular}{cccc}
\hline Model & R Square & Adjusted R Square & Durbin-Watson \\
\hline 1 & .168 & .131 & 2.058 \\
\hline
\end{tabular}

Sumber : Data diolah, 2019 


\section{Uji heteroskedastisitas}

Berdasarkan Gambar 4 menunjukkan scatterplot memperlihatkan bahwa titik menyebar disekitar angka 0 . dapat disimpulkan bahwa tidak terjadi heteroskedastisitas.

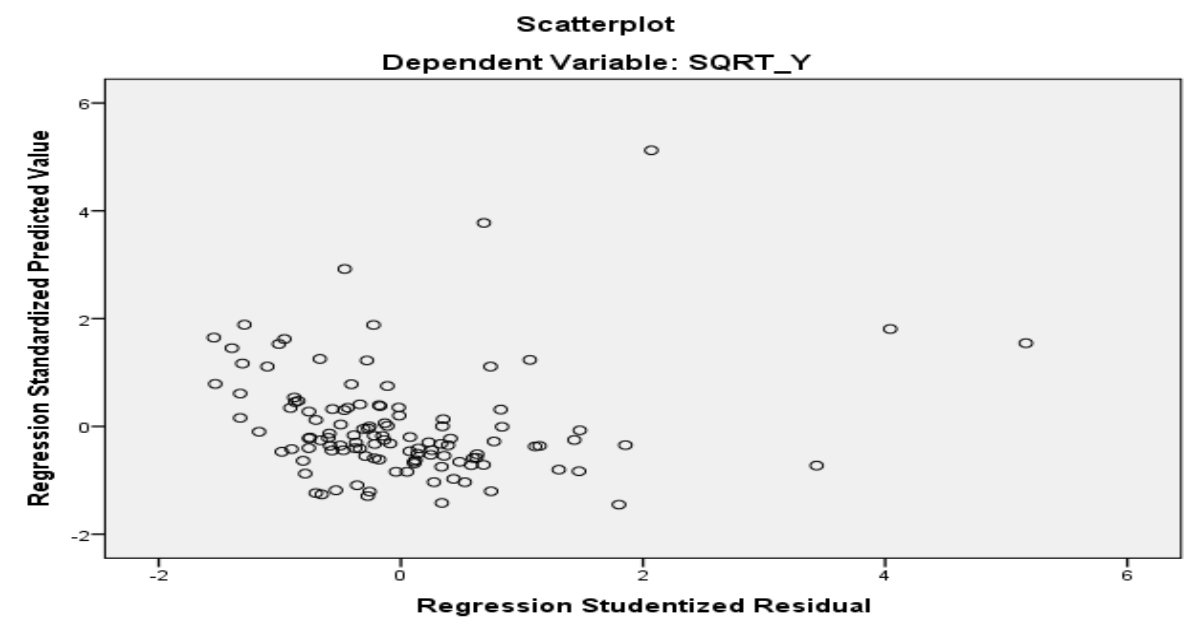

Sumber : Data diolah, 2019

Gambar 4. Uji heteroskedastisitas setelah transformasi sqrt

\section{Hasil analisis data penelitian}

Model penelitian

Pengujian model ini memakai analisis regresi linear berganda.

Tabel 6. Persamaan regresi linear berganda

\begin{tabular}{|c|c|c|c|c|c|}
\hline \multirow{2}{*}{ Model } & \multicolumn{2}{|c|}{ Unstandardized Coefficients } & \multirow{2}{*}{$\begin{array}{c}\begin{array}{c}\text { Standardized } \\
\text { Coefficients }\end{array} \\
\text { Beta }\end{array}$} & \multirow{2}{*}{$\mathbf{t}$} & \multirow{2}{*}{ Sig. } \\
\hline & B & Std. Error & & & \\
\hline 1 (Constant) & .766 & .471 & & 1.626 & .107 \\
\hline SQRT_ROA & .445 & .115 & .557 & 3.883 & .000 \\
\hline SQRT_DAR & -.444 & .510 & -.139 & -.871 & .386 \\
\hline SQRT_CR & -.067 & .061 & -.124 & -1.090 & .278 \\
\hline SQRT_DER & .170 & .115 & .246 & 1.480 & .142 \\
\hline SQRT_EPS & -.012 & .008 & -.155 & -1.479 & .142 \\
\hline
\end{tabular}

Sumber : Data diolah, 2019

\section{PBV $=0.766+0.445 R O A-0.444 D A R-0.067 C R+0.170 D E R-0.012 E P S$}

Dengan menggunakan sqrt maka dapat diambil kesimpulan: 1).Konstanta sebesar 0,766 satuan menjelaskan return on assets, debt to total assets ratio, current ratio, debt to equity rasio, earning per share bernilai konstan maka price to book value sebesar 0,766. 2).Koefisiensi regresi Return On Assets (ROA) dengan nilai 0,445 satuan menjelaskan bahwasannya pada tiap-tiap kenaikan yang terjadi pada setiap per satuan ROA dapat mengakibatkan adanya kenaikan nilai 0,445 yang terjadi pada Price to Book Value. 3).Koefisiensi regresi Debt to Total Assets Ratio (DAR) senilai -0,444 satuan menjelaskan bahwasanya tiap-tiap kenaikan per satuan Debt to Total Assets Ratio (DAR) akan mengakibatkan nilai menjadi turun 0,444. 4).Koefisiensi regresi Current Ratio sebesar -0,067 satuan menjelaskan bahwasannya pada tiap-tiap kenaikan per satuan dari Current Ratio akan menyebabkan penurunan Price to Book Value (PBV) senilai 0,067.5).Koefisiensi regresi Debt to Equity Ratio (DER) dengan total 0,170 menjelaskan 
bahwaannya pada tiap-tiap kenaikan per satuan dari Debt to Equity Ratio (DER) akan mengakibatkan adanya kenaikan 0,170 yang terjadi pada Price to Book Value (PBV). 6).Koefisiensi regresi Earning Per Share (EPS) senilai -0,012 menjelaskan bahwasannya tiap-tiap kenaikan per satuan dari Earning Per Share (EPS) akan mengakibatkan adanya kenaikan 0,012 yang terdapat pada Price to Book Value (PBV).

Koefisien determinasi hipotesis

Tabel 7. Uji koefisien determinasi

\begin{tabular}{crrrr}
\hline Model & R & R Square & Adjusted R Square & \multicolumn{2}{c}{$\begin{array}{c}\text { Std. Error of the } \\
\text { Estimate }\end{array}$} \\
\hline 1 & $.410^{\mathrm{a}}$ & .168 & .131 & .52935 \\
\hline
\end{tabular}

Sumber : Data diolah, 2019

Tabel 7, memperlihatkan nilai Adjusted $R$ Square sebesar 13,1\% dari variasi variabel terikat PBV akan di jabarkan variabel bebas dan sisanya senilai $86,9 \%$ dipaparkan variabel lain dari luar penelitian ini.

\section{Pengujian hipotesis secara simultan (Uji F)}

Berdasarkan Tabel 8 memberikan hasil nilai $F_{\text {hitung }}$ sebesar 4,486. Dengan derajat bebas $1(\mathrm{df})=5$ serta $2\left(\mathrm{df}_{2}\right)=111$. Nilai $\mathrm{f}_{\text {tabel }}$ dalam tingkat kepercayaannya sig 0,05 sebesar 2,30. $\mathrm{F}_{\text {hitung }}=4,486>\mathrm{F}$ tabel $=2,30$ dengan tingkatan signifikan $0,001^{\mathrm{b}}$. Dikarenakan $F_{\text {hitung }}>\mathrm{F}_{\text {tabel }}$ serta sig $<0,05$ maka $\mathrm{H}_{\mathrm{a}}$ diterima dengan kata lain secara simultan "Return On Assets", "Debt to Total Assets Ratio", "Current Ratio", "Debt to Equity Ratioo", "Earningi Per Share” berpengaruh secara signifikan pada Pricee to Book Value di perusahaan sektor keuangan yang tercatat di BEI tahun 2015-2017.

Tabel 8. Uji simultan ( uji f) setelah transformasi sqrt

\begin{tabular}{llrrrrr}
\hline \multicolumn{1}{c}{ Model } & Sum of Squares & Df & Mean Square & F & Sig. \\
\hline \multirow{4}{*}{1 Regression } & 6.286 & 5 & 1.257 & 4.486 & \\
1 Residual & 31.104 & 111 & .280 & & \\
& Total & 37.389 & 116 & & & \\
\hline
\end{tabular}

Sumber : Data diolah, 2019

\section{Pengujian hipotesis secara parsial}

Berdasarkan hasil statistik t pada tabel 9 sebagai berikut: 1).Variabel Profitabilitas dilambangkan dengan ROA mempunyai $t_{\text {hitung }} 3,883$ dan $t_{\text {tabel }}$ diperoleh sebesar 1,65870 yang diperoleh dari $t_{\text {tabel }}$ dengan $d f=111$. Sehingga $t_{\text {hitung }}>t_{\text {tabel }}(3,883>1,65870)$ berdasarkan pada signifikasi nilai dengan yaitu $0,000<0,05$.

Tabel 9. Uji parsial (uji t)

\begin{tabular}{|c|c|c|c|c|c|c|}
\hline \multicolumn{2}{|c|}{ Model } & \multicolumn{2}{|c|}{$\begin{array}{c}\text { Unstandardized } \\
\text { Coefficients }\end{array}$} & \multirow{2}{*}{$\begin{array}{c}\begin{array}{c}\text { Standardized } \\
\text { Coefficients }\end{array} \\
\text { Beta } \\
\end{array}$} & \multirow{2}{*}{$\mathbf{t}$} & \multirow{2}{*}{ Sig. } \\
\hline & & B & Std. Error & & & \\
\hline \multirow[t]{6}{*}{1} & (Constant) & .766 & .471 & & 1.626 & .107 \\
\hline & SQRT_ROA & .445 & .115 & .557 & 3.883 & .000 \\
\hline & SQRT_DAR & -.444 & .510 & -.139 & -.871 & .386 \\
\hline & SQRT_CR & -.067 & .061 & -.124 & -1.090 & .278 \\
\hline & SQRT_DER & .170 & .115 & .246 & 1.480 & .142 \\
\hline & SQRT_EPS & -.012 & .008 & -.155 & -1.479 & .142 \\
\hline
\end{tabular}

Sumber : Data diolah, 2019 
Berdasarkan $\mathrm{H}_{\mathrm{a}}$ diterima dan $\mathrm{H}_{\mathrm{o}}$ yakni ROA berepengaruh positif dan signifikansi pada PBV pada perusahaan sektor keuangan tahun 2015-2017. 2).Variabel Leverage dilambangkan dengan DAR memiliki $t_{\text {hitung }}-0,871$ dan $t_{\text {tabel }}$ diperoleh sebesar 1,65870 yang diperoleh dari $t_{\text {tabel }}$ dengan $\mathrm{df}=111$. Maka $\mathrm{t}_{\text {hittung }}<\mathrm{t}_{\text {tabel }}(-0,871>-1,65870)$ pada nilai sig 0,386 >0,05. Menunjukan DAR tidak memiliki penagaruh dan tidak signifikan. 3).Variabel Likuiditas dilambangkan dengan CR memiliki $t_{\text {hitung }}-1,090$ dan $t_{\text {tabel }}$ diperoleh sebesar 1,65870 yang diperoleh dari $\mathrm{t}_{\text {tabel }}$ dengan $\mathrm{df}=111$. Maka $\mathrm{t}_{\text {hitung }}\left\langle\mathrm{t}_{\text {tabel }}(-1,090\rangle-\right.$ 1,65870) pada nilai sig 0,278 >0,05. Menunjukan Current Ratio tidak terdapat pengaruh dan tidak signifikan. 4).Variabel Struktur Modal dilambangkan dengan DER memiliki $t_{\text {thitung }} 1,480$ dan $t_{\text {tabel }}$ diperoleh sebesar 1,65870 yang diperoleh dari tabel dengan $\mathrm{df}=111$. Apabila $t_{\text {hitung }}<t_{\text {tabel }}(1,480<1,65870)$ pada nilai sig $0,142>0,05$. Ini menunjukan bahwasannya DER tidak terdapat pengaruh dan tidak signifikan. 5).Variabel Keputusan Investasi dilambangkan dengan EPS memiliki thitung $-1,479$ dan $t_{\text {tabel }}$ diperoleh sebesar 1,65870 yang diperoleh dari $t_{\text {tabel }}$ dengan $\mathrm{df}=111$. Maka $\mathrm{t}_{\text {hitung }}<\mathrm{t}_{\text {tabel }}(-1,479>-1,65870)$ pada nilai sig 0,142>0,05. Ini menunjukan bahwasanya EPS tidak terdapat pengaruh dan tidak signifikan.

\section{Pengaruh profitabilitas terhadap nilai perusahaan}

Hasil uji parsial didapatkan nilai $t_{\text {hitung }}$ yaitu 3,883 > pada $t_{\text {tabel }} 1,65870$ ), sesuai nilai sig $0.000<0.05$. Maka membuktikan bahwasanya profitabilitas memiliki pengaruh signifikansi atas nilai perusahaan atas perusahaan sektor keuangan yang tercatat BEI tahun 2015-2017. Berarti meningkatnya Profitabilitas akan mendorong nilai perusahaan. Ditemukan jurnal pendukung oleh Dewi dan Wirajaya (2013) yaitu profitabilitas memiliki pengaruh secara signifikansi pada nilai perusahaan.

\section{Pengaruh leverage terhadap nilai perusahaan}

Sesuai dari hasil uji $t$ didapatkan $t_{\text {hitung }}-0,871>t_{\text {tabel }}-1,65870$ pada nilai sig yakni $0,386>0,05$. Menunjukkan Leverage tidak memiliki pengaruh dan tidak signifikansi pada nilai perusahaan pada perusahaan sektor keuangan yang tercatat pada BEI tahun 2015-2017. Dalam hal ini sependapat pada riset Novari dan Lestari (2016) menunjukkan Leverage tak mempunyai pengaruh pada nilai perusahaan. Dimana perusahaan memiliki kecenderungan dalam penggunaan dananya sendiri untuk membiayai aktivanya daripada hutang. Penggunaan utang yang banyak tidak akan berdampak atas harga saham dan nilai perusahaan.Akan tetapi tidak sependapat pada hasil riset Rudangga dan Sudiarta (2016) yang menunjukkan Leverage memiliki pengaruh positif pada nilai perusahaan. Riset ini menghasilkan bahwa tingginya Leverage dikatakan tidak terdapat pengaruh nilai perusahaan terjadi peningkatan.

\section{Pengaruh likuiditas terhadap nilai perusahaan}

Hasil uji parsial didapatkan, $t_{\text {hitung }}$ yakni $-1,090>t_{\text {tabel }}$ yaitu $-1,65870$ pada nilai sig $0,278>0,05$. Menyatakan bahwasanya Likuiditas tidak memiliki pengaruh serta tidak signifikansi pada nilai perusahaan atas perusahaan sektor keuangan yang terdata di BEI tahun 2015-2017. Riset ini sependapat dengan penelitian Wulandari (2013) Likuiditas tidak didapatkan pengaruh atas nilai perusahaan. Artinya tingginya Likuiditas justru dapat menimbulkan turunnya Nilai Perusahaan, karena manajemen perusahaan tidak memanfaatkan aset yang menganggur.

Namun tidak sependapat dengan penelitian Afriyani dan Jumria (2020) yaitu Likuiditas memiliki pengaruh baik dan signifikansi atas nilai perusahaan. 


\section{Pengaruh struktur modal terhadap nilai perusahaan}

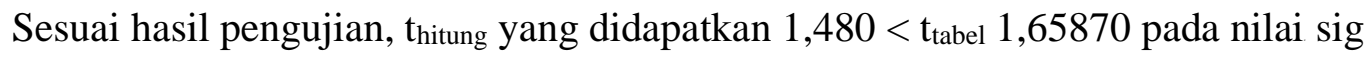
$0,142>0,05$. Berdasarkan pengolahan data ditemukannya bahwa Struktur Modal tidak memilikin pengaruh dan tidak signifikansi pada nilai perusahaan atas perusahaan sektor keuangan yang terdata pada BEI tahun 2015-2017. Hasil riset ini sependapat dengan Artini dan Puspaningsih (2011) menunjukkan struktur modal tidak terdapat pengaruh pada nilai perusahaan. Artinya pemakaian utang akan menyebabkan wajibnya membayar bunga yang dapat menimbulkan laba serta jumlahnya deviden dapat berkurang. Akan tetapi hasil riset ini tidak searah dengan Manoppo dan Arie (2016) yang menunjukkan strukur modal didapatkan pengaruh nilai perusahaan.

\section{Pengaruh keputusan investasi terhadap nilai perusahaan}

Sesuai $t_{\text {hitung }}$ yang didapatkan $-1,478>-1,65870$ pada nilai sig $0,142>0,05$. ini memperlihatkan bahwasanya keputusan investasi tidak memiliki pengaruh dan tidak signifikansi pada nilai perusahaan atas perusahaan sektor keuangan yang tercatat pada BEI tahun 2015-2017. Hasil riset ini sependapat dengan Salama, dkk (2019) yang menghasilkan putusan Investasi berpengaruh negatif pada nilai perusahaan. artinya terdapat faktor ketidakpastian seperti kondisi sosial ekonomi, perubahan teknologi dan kebijakan pemerintah dimasa selanjutnya.Hasil riset ini tidak searah dengan Rajagukguk, dkk (2019) yang menghasilkan Keputusan Investasi memiliki pengaruh positif pada Nilai Perusahaan.

\section{KESIMPULAN DAN SARAN}

\section{Kesimpulan}

Profitabilitas secara sebagian (parsial) berpengaruh positif dan signifikansi pada nilai perusahaan di perusahaan sektor keuangan yang sudah masuk pada daftar Bursa Efek Indonesia. Leverage secara sebagian (parsial) tidak mempunyai penagaruh serta tidak signifikan pada nilai perusahaan di perusahaan dengan sektor keuangan yang telah masuk di daftar Bursa Efek Indonesia. Likuiditas secara sebagian (parsial) tidak memiliki pengaruh dan tak signifikansi atas nilai perusahaan di perusahaan dengan sektor keuangan yang telah masuk di daftar Bursa Efek Indonesia. Struktur Modal secara sebagian (parsial) tidak mempunyai pengaruh dan tidak signifikansi atas Nilai Perusahaan di perusahaan dengan sektor keuangan yang telah masuk di daftar Bursa Efek Indonesia. Keputusan investasi secara parsial tidak terdapat pengaruh dan tidak signifikansi atas nilai perusahaan di perusahaan sektor keuangan yang tercatat pada Bursa Efek Indonesia.Profitabilitas, leverage, likuiditas, struktur modal dan putusan investasi mempunyai pengaruh serta signifikansi secara simultan di perusahaan dengan sektor keuangan yang telah masuk di daftar Bursa Efek Indonesia.

\section{Saran}

Berdasarkan penelitian yang telah kami lakukan, maka dari itu peneliti memberikan saran sebagai berikut : 1).untuk peneliti di masa mendatang peneliti snagat mengharap bahwa hasil dari penelitiaan yang dilakukannya dapat memberikan sumbangsih berupa untuk referensi dan pertimbangan untuk memperdalam bagi penelitian selanjutnya dengan menggunakan rasio dan objek penelitian yang berbeda serta tingkat keluasan terhadap laporan keuangan pada bursa efek indonesia. 2).bagi perusahaan sebaiknya dilakukan perbaikan kinerja dalam perusahaan, karena laba yang besar pun jika memiliki hutang yang besar atau bahkan melebihi laba yang dihasilkan akan memiliki resiko yang memicu nilai perusahaan menurun. dalam kata lain, yaitu jika 
suatu perusahaan mempunyai nilai yang tinggi, maka dapat memicu minat para investor dalam mengembangkan tanam modalnya.3).untuk investor sebaiknya investor memperkirakan level kecukupan modal dan tingkat likuiditas dalam perusahaan sebelum mengambil keputusan, karena hal tersebut memberikan berpengaruh pada naik turunnya harga saham dan juga memiliki pengaruh atas nilai perusahaan.

\section{DAFTAR PUSTAKA}

Brigham, E.F., \& Houston, J.F. (2012). Dasar-dasar manajemen keuangan. Edisi V. Salemba Empat: Jakarta

Darmadji, Tjiptono \& Fakhruddin. (2012). Pasar modal di indonesia. Edisi. Ketiga. Salemba Empat: Jakarta

Fahmi, Irham. (2015). Pengantar manajemen keuangan teori dan soal jawaban. Alfabeta: Bandung

Ghozali, Imam. (2016). Aplikasi analisis multivariate dengan program IBM SPSS 23, Edisi 8 Cetakan VIII. Badan Penerbit Universitas Diponegoro: Semarang

Hani, Safriida. (2015). Metode analisa laporan keuangan. UMSU PRESS: Medan

Harahap, Sofyan Syafri. (2015). Analisis kritis atas laporan keuangan. PT. Raja Grafindo Persada: Jakarta

Hermawan, A., \& Yusran, H.L. (2017). Penelitian bisnis pendekatan kuantitatif. Kencana: Depok

Husnan, Suad Dan Pudjiastuti, Enny. (2012). Dasar-dasar manajemen keuangan. UPP STIM YKPN: Yogyakarta

Kasmir. (2012). Analisis laporan keuangan. PT Raja Grafindo Persada: Jakarta

Mulyawan, Setia. (2015). Manajemen keuangan. Cetakan Pertama, CV Pustaka Setia: Bandung

Noor, Henry Faizal. (2014). Investasi, pengelolaan keuangan, dan pengembangan ekonomi masyarakat. Edisi Revisi, Mitra Wacana Media: Jakarta

Priyatno, Duwi. (2013). Mandiri belajar analisis data dengan SPSS, Mediakom: Yogyakarta

Sartono, Agus. (2010). Manajemen keuangan teori dan aplikasi. Edisi 4. Yogyakarta: BPFE: Yogyakarta

Sudana, I Made. (2012). Manajemen keuangan perusahaan teori \& praktik. Erlangga: Jakarta

Sugiono, Arief dan Edi Untung. (2016). Panduan praktis dasar analisa laporan keuangan. Cetakan Pertama, Grasindo: Jakarta

Sugiyono. (2017). Metode penelitian bisnis (pendekatan kuantitatif, kualitatif, dan $R \& D$. Cetakan ke-15. Alfabeta, CV: Bandung

Syamsuddin, Lukman. (2011). Manajemen keuangan perusahaan - konsep aplikasi dalam perencanaan, pengawasan, dan pengambilan keputusan. PT. Raja Grafindo Persada: Jakarta

Widoatmodjo, Sawidji. (2012). Cara cepat memulai investasi sahan panduan bagi pemula. PT Elex Media Komputindo: Jakarta. 